\title{
A sea of islands, a sea of crime: island crime fiction in the Aegean Sea
}

\author{
Ralph Crane \\ University of Tasmania, Australia \\ Ralph.Crane@utas.edu.au
}

\begin{abstract}
Crime fiction frequently takes the real and imaginary geography of islands as its setting and subject. Through a reading of selected novels by Anne Zouroudi, Jeffrey Siger, and Paul Johnston, this article looks at ways in which ideas about 'islandness' operate in contemporary English-language crime fiction set in the Aegean Sea. Specifically, it uses geocriticism and spatial literary studies to explore the ways non-textual paratext-in particular covers and maps - work alongside a text, or narrative, to capitalize on the lure of islands.
\end{abstract}

Keywords: Aegean Sea, book covers, crime fiction, islands, literary and narrative maps

https://doi.org/10.24043/isj.85

(C) 2019-Institute of Island Studies, University of Prince Edward Island, Canada.

\section{Introduction}

In 1958 Yannis Maris (2016) chose the cosmopolitan Aegean island and popular tourist destination of Mykonos as the setting for his first Commissar Becas (Inspector Bekas) novelpublished in English almost fifty years later as Murder in Mykonos (or Crime in Mykonos). Maris is often referred to as the founder, or father, of Greek crime fiction (see, for example, Kaisidou, 2018), and his influence on the genre in Greece (and Mediterranean noir more broadly) has been enormous. Indeed, Filippos Filippou (2015, p. 145) (himself a prominent crime writer) suggests of the recent wave of Greek crime writers that "all of them, more or less, followed in his tracks and for this reason some of them like to be known as 'Yannis Maris's children'." Maris's influence also extends to non-Greek writers who choose the islands of the Aegean as settings for their crime fiction. Notably, the American writer Jeffrey Siger echoes Maris in the title of his first Andreas Kaldis crime novel, Murder in Mykonos (2009), while the English writer Anne Zouroudi references Maris's later Inspector Bekas adventure, The Fourth Suspect (not published in English), in The Gifts of Poseidon (2016), the eighth of her Mysteries of the Greek Detective series.

The enduring popularity of the Greek islands as a setting for English-language crime fiction and thrillers is readily demonstrated. Agatha Christie's 'Triangle at Rhodes', one of four novella-length Poirot stories collected in Murder in the Mews (1937), is set on the largest of the Dodocanese islands. Jack Higgins chooses the fictional Greek islands of Kyros and Sinos as the principal settings for his novels The Dark Side of the Island (1963) and Night Judgement at 
Sinos (1970), while in Colonel Sun (1968), the first James Bond continuation novel, penned by Kingsley Amis (writing as Robert Markham), Bond follows the trail of the kidnapped M to the fictional Aegean island of Vrakonski. Clive Cussler's first Dirk Pitt adventure thriller, The Mediterranean Caper (1973), is set on the northernmost Greek island of Thasos. The appeal of islands as exotic or remote locations is manifest in the eponymous island of Alistair MacLean's adventure thriller Santorini (1986), which borrows its title from the Cycladic island, and includes a paratextual literary map of the Aegean Sea, with an inset map of Thera (Santorini), even though the action of the novel takes place near rather than on the islandprimarily aboard the frigate Ariadne. Into the Blue (1990), the first of Robert Goddard's three mystery-thrillers featuring Harry Barnett, begins on the island of Rhodes, while Julia Crouch's psychological thriller, The Long Fall (2014), is set on the North Aegean island of Ikaria.

In his Introduction to The Cambridge Companion to Crime Fiction, Martin Priestman (2003, p. 2) persuasively argues that "As the crime genre [...] developed [...] it became increasingly relevant to consider the gender, race, and class implications of its various metamorphoses." These considerations, all important, tend to pay particular attention to character and plot, key pillars of the novel favoured by literary critics; but what of the often neglected territory of setting? And, more particularly, what of the islands that occur so frequently as settings for crime novels? As Barbara Pezzotti (2014, p. 125) explains, "The island is an ideal setting for a detective story." The island geography "with its natural boundaries seems to guarantee an enlarged version of the mystery of the enclosed chamber. It offers the opportunity to take up some core elements from the golden age of detective fiction that would appear impossibly stilted if set on the modern mainland" (Pezzotti, 2014, p. 125). She is suggesting, in other words, that writers of crime fiction are attracted by the possibilities of the insular geography that is key to the identity of (particularly) small islands. Both the physical space (the island) and the islandness, which Francois Taglioni (2011, p. 47) defines as "the sum of representations and experiences of islanders," can be exploited by crime writers in the initial murder and/or the ensuing investigation. Island settings are not accidental to crime fiction; while crime novels can be, and are, set anywhere, the geography of islands enables specific conventions of the genre. And, in a broader sense, as Elizabeth Leane (2016, p. 26) observes, "The assumption that text and place are co-constitutive is increasingly recognized within cultural geography as well as spatial literary studies." From the golden age of detective fiction through to the more recent wave of noir crime (Nordic noir; Tartan noir), from Agatha Christie and Margery Allingham to Mari Jungstedt and Peter May, numerous writers have succumbed to the lure of islands. As Lisa Fletcher and I point out in Island Genres, Genre Islands, "Islands are everywhere in the atlas of crime fiction" (Crane \& Fletcher, 2017, p. 3); and for the crime writers discussed in this article, there is frequently "an island where there's trouble brewing" (Zouroudi, 2011b, p. 64).

In the last two decades Siger, Zouroudi, and Scottish writer Paul Johnston (all of whom live, or have lived in Greece) have published crime novels set on the islands of the Aegean. Five of the eight novels in Zouroudi's Mysteries of the Greek Detective series-The Messenger of Athens (2007); The Lady of Sorrows (2010); The Whispers of Nemesis (2011); The Bull of Mithros (2012); and The Gifts of Poseidon — are set on the imaginary Greek islands of Thiminos, Kalkos, Sefros, Mithros, and Liteos (loosely based on Alonissos, in the Sporades group of islands), respectively. Siger signals their real island settings in the titles of four of his nine Chief Inspector Andreas Kaldis series: Murder in Mykonos; Target Tinos (2012); Mykonos After 
Midnight (2013); and Santorini Caesars (2016). The title of his latest novel, An Aegean April (2018), set on the island of Lesvos, emphasizes the aquapelagic connection between the island and the surrounding sea. And three of Johnston's seven Alex Mavros mysteries have island settings: Crying Blue Murder (originally published as A Deeper Shade of Blue, 2002), set on the imaginary island of Trigono; The Silver Stain (2011), set largely on Crete; and The White Sea (2014), which is set in part on Lesvos (see Table 1).

Table 1: Summary of selected texts.

\begin{tabular}{|c|c|c|c|}
\hline Author & Series & Island-Set Novels in Series & Island Setting \\
\hline $\begin{array}{l}\text { Anne Zouroudi, } \\
\text { English }\end{array}$ & $\begin{array}{l}\text { Mysteries of the } \\
\text { Greek } \\
\text { Detective: } \\
8 \text { novels in series }\end{array}$ & $\begin{array}{l}\text { The Messenger of Athens (2007) } \\
\text { The Lady of Sorrows (2010) } \\
\text { The Whispers of Nemesis (2011) } \\
\text { The Bull of Mithros (2012) } \\
\text { The Gifts of Poseidon (2016) }\end{array}$ & $\begin{array}{l}\text { Thiminos (imaginary) } \\
\text { Kalkos (imaginary) } \\
\text { Sefros / Kerkyra (imaginary) } \\
\text { Mithros (imaginary) } \\
\text { Liteos (imaginary) }\end{array}$ \\
\hline $\begin{array}{l}\text { Jeffrey Siger, } \\
\text { American }\end{array}$ & $\begin{array}{l}\text { Chief Inspector } \\
\text { Andreas Kaldis } \\
\text { Mysteries: } \\
9 \text { novels in series }\end{array}$ & $\begin{array}{l}\text { Murder in Mykonos (2009) } \\
\text { Target Tinos (2012) } \\
\text { Mykonos After Midnight (2013) } \\
\text { Santorini Caesars (2016) } \\
\text { An Aegean April (2018) }\end{array}$ & $\begin{array}{l}\text { Mykonos (actual) } \\
\text { Tinos (actual) } \\
\text { Mykonos (actual) } \\
\text { Santorini (actual) } \\
\text { Lesvos (actual) }\end{array}$ \\
\hline $\begin{array}{l}\text { Paul Johnston, } \\
\text { Scottish }\end{array}$ & $\begin{array}{l}\text { Alex Mavros } \\
\text { Mysteries: } \\
7 \text { novels in series }\end{array}$ & $\begin{array}{l}\text { Crying Blue Murder (2002) } \\
\text { The Silver Stain (2011) } \\
\text { The White Sea (2014) }\end{array}$ & $\begin{array}{l}\text { Trigano (imaginary) } \\
\text { Crete (actual) } \\
\text { Lesvos (actual) }\end{array}$ \\
\hline
\end{tabular}

Literary geographers already know that, as Sarah Luria (2011, p. 67) succinctly puts it, "geography can help us understand literature and literature can help us understand geography." Using the Greek island-set crime novels of Zouroudi, Siger, and Johnston as case studies, this article argues that what holds true in the wider sense for geography and literature also holds true when the focus is narrowed to island studies. Specifically, it builds on my work with Lisa Fletcher in Island Genres, Genre Islands, to demonstrate the ways islands can help us understand crime fiction and crime fiction can help us understand islands. It combines 'distant' and 'close' readings of Aegean island-set crime fiction, drawing on literary studies, cultural studies, and tourism studies to read two paratextual elements of the books - covers and maps - in order to explore the co-constitutive relationship between island setting and genre text. Like western culture, crime fiction "not only thinks about islands, but thinks with them" (Gillis, 2003, p. 1).

\section{Reading covers}

As Nicole Matthews (2007, p. xi) crisply explains, "book covers-the wrapping of image, typography and puff prose that surrounds the written contents of a book-really matter. They matter because, despite the turn of phrase that admonishes us not to do it, as readers, we do indeed judge books by their covers." The island settings of the crime novels discussed here are frequently signalled to greater or lesser degrees on their covers, which are intended to convey "a message about the contents of the volume, influencing both the retailer who stocks the book and the potential purchaser in the shop" (Phillips, 2007, p. 19). Generally, the cover of a novel "may echo the book's plot or characters" (Phillips, 2007, p. 19), or, in the case of 
a crime novel, be designed to evoke mystery or danger. In the case of island crime fiction, however, the cover frequently references setting: publishers assume islands are attractive to the potential reader/purchaser. And this announcement of islandness is reinforced by the text on the covers - the titles, straplines, and so on. Siger's title, Santorini Caesars, for example, clearly announces the novel's Greek island setting, while the strapline on the cover of Zouroudi's The Lady of Sorrows ("The Mysteries of the Greek Detective") provides the geography her title lacks.

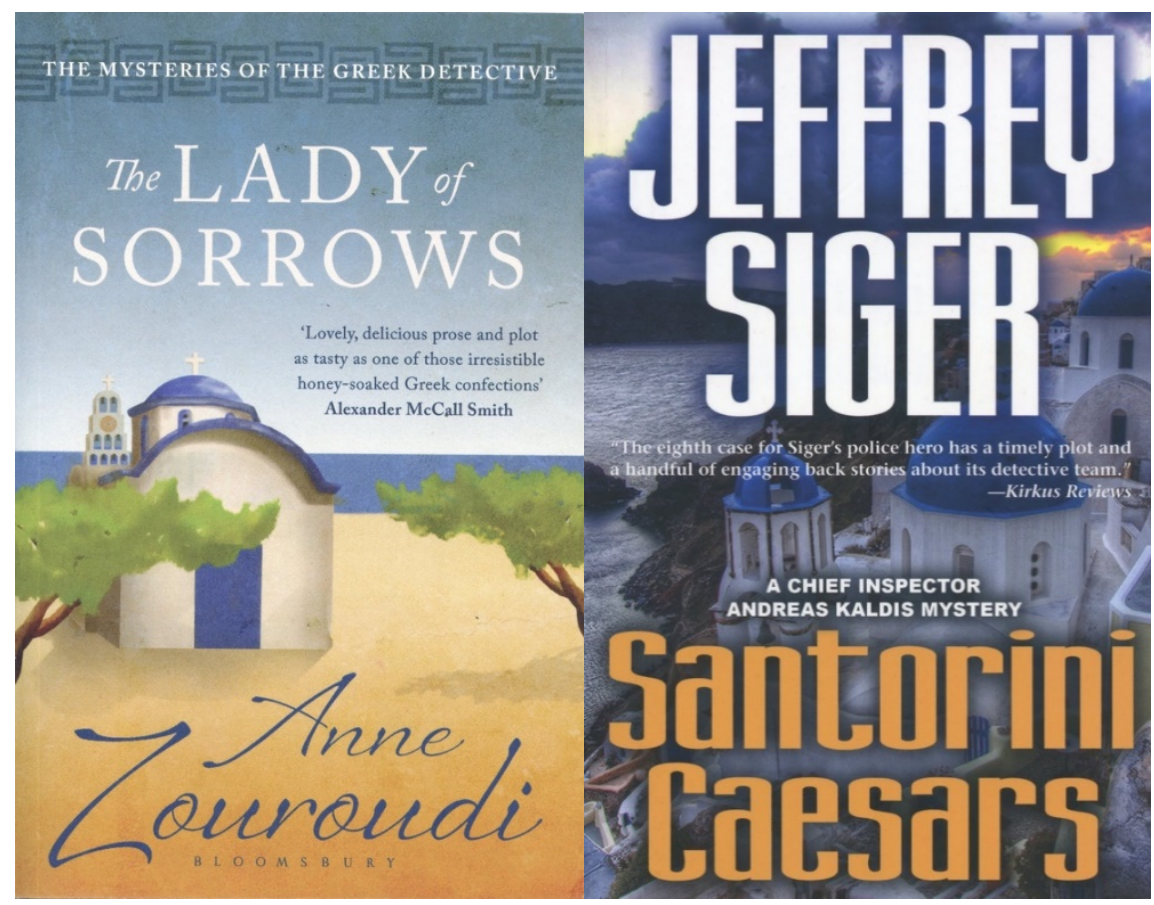

Figure 1: Anne Zouroudi, The Lady of Sorrows, Bloomsbury, 2011 (left); Jeffrey Siger, Santorini Caesars, Poisoned Pen Press, 2016 (right).

The cover designs of both novels (Figure 1) emphasize their Greek island settings through the proximity of the sea and the ubiquitous white-walled, blue-domed churchessymbolizing the white of the Aegean Sea and the blue of the Greek sky-which specifically conjure the Cyclades Islands. The design of Zouroudi's cover, with its promise of sun, sand, and warm seas - key island features in western discourse-imagines when and where the book might be read, and targets holiday readers and readers of popular fiction in general, but not specifically readers of crime. Without the strapline, this cover (including Alexander McCall Smith's puff that promises "Lovely, delicious prose and plot as tasty as one of those irresistible honey-soaked Greek confections") could readily signal a romance (and, indeed, the covers of the Berkley editions of Nora Roberts' Guardians Trilogy use similar images to attract readers). Like the covers favoured by tourist brochures and guidebooks, the design shorthand seems to deploy the island as a site of wish-fulfilment rather than a site of threat or danger. It invites would-be purchasers to read the book in advance of a Greek island holiday, to read the book on a beach during a Greek island holiday, or to read it after returning home from a Greek island holiday. The altogether darker nature of Siger's work is foreshadowed in the almost gothic design of its cover. The storm clouds gathering over the island cast their shadow over the jagged cliffs and rocky shoreline, turning the sea grey and dulling the blue-and-white 
architecture. The covers (accurately) suggest that Zouroudi's novel is a lighter read than Siger's-more cozy than noir. Yet in their several ways, the covers of both books recognize the brand value of "the island lure" (Baldacchino, 2012, p. 56), and actively participate in what Godfrey Baldacchino (2012, p. 55) suggests "may be the most lavish, global and consistent branding exercise in human history."

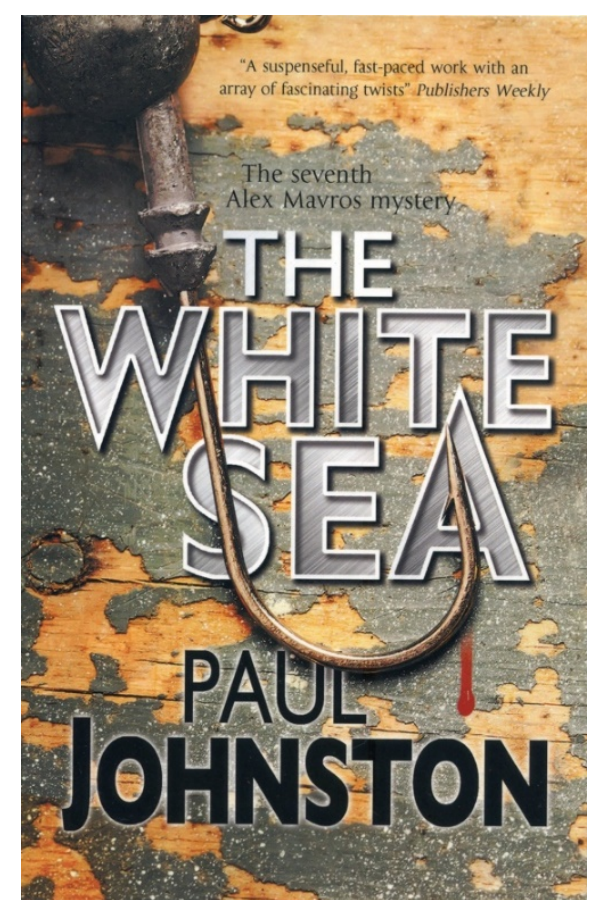

Figure 2: Paul Johnston, The White Sea, Crème de la Crime, 2014.

The title of Johnston's The White Sea (Figure 2), a synonym for the island-dotted Aegean Sea, immediately signals its geographical location and anticipates its marine and island settings. This is reinforced by the cover design which portrays flaking wooden boards on which a fishhook (or pirate hook), dripping blood, rests. While the cover is obviously designed to signal the genre of crime (or adventure) fiction, it also consciously responds to "the island lure" in its clever use of the flaking paint and exposed wood which can be read as a stylized map of the White Sea and its many islands.

The focus on the landscape on the covers of island-set crime novels adds to the sense of remoteness, isolation, and boundedness that the setting provides. The designs of the three covers discussed above (as well as the other island-set novels in these several series) implicitly acknowledge that islands evoke particular kinds of intimacies which allow certain kinds of crime story-ones that have their antecedents in both the locked-room mysteries of the golden age of crime fiction, whose enclosed settings are echoed in the closed or bounded spaces of islands, and the Robinsonades and other island adventure fictions of the $18^{\text {th }}$ and $19^{\text {th }}$ centuries.

\section{Reading maps}

In crime fiction maps are commonly positioned at the front of the book, so that they are encountered and read before the text, and are there to be consulted as necessary during the course of reading the narrative. While they rarely include the level of detail that is common 
to maps in fantasy fiction, the maps that accompany Zouroudi's series are an exception. The map located at the beginning of The Messenger of Athens (Figure 3) includes orientation and some topographical detail such as oblique hill signs; the maps in Zouroudi's other novels also include topographical details (coastlines, mountains), as well as other features such as villages and roads, but no orientation. More in common with those widely found in the genre, the maps in Siger's novels show orientation, but no topographical details.

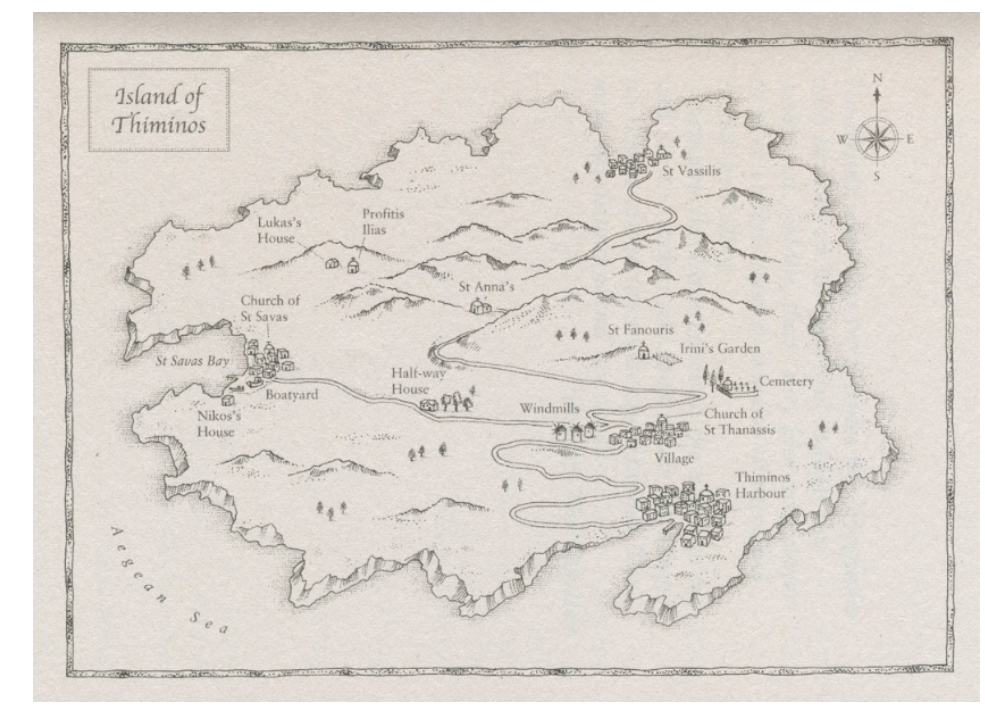

Figure 3: Map of the Island of Thiminos, by John Gilkes. Anne Zouroudi, The Messenger of Athens, Bloomsbury, 2011.

With the exception of The Gifts of Poseidon, the most recent of Anne Zouroudi's Hermes Diaktoros mysteries, each novel in her Mysteries of the Greek Detective series is preceded by a fictional map of the setting drawn by map artist John Gilkes. Interestingly, the map of the imaginary island of Thiminos (Figure 3), which precedes the text in The Messenger of Athens, is the only map in the series which shows the whole circumference of an island. This map, which, like the others in the series, is not referenced in the text, provides a vivid visual impression of the geography and forbidding topography of the "huge rock" (p. 24). Together with the early description of Thiminos from the sea, the map works to emphasize from the outset the importance of spatiality in Zouroudi's novel:

From the sea, the island of Thiminos showed exactly what it was: rock, one huge rock, so undercut by the salt water of the southern Aegean it seemed to float free, rising and falling in the swell. Mostly, the cliff faces of its coasts were sheer; where the slopes were gentler, they were all thin dirt and stone. There was little else: a few black pines rooted into the mountainsides at improbable angles; thorny, run-down shrubs between the boulders. And yet, here and there, it held a colourful surprise-on an empty beach, a tiny, white chapel in a garden of fresh, fuchsia-blossomed evergreens.

It was an island with no beauty of its own, but around its shores, where the sea ran the gamut of all blues - turquoise and lapis lazuli, sapphire, ultramarine and cobalt the water and sunlight changed it. Grey rocks on the beach shone silver; there was gold in the dull soil on the mountain slopes. Fool's gold. Tricks of light.

There was one way in and one way out: by sea. (Zouroudi, 2011a, p. 24) 
This description collaborates with the already seen map to emphasize the inhospitable landscape that comprises sheer cliffs, black pines, and thorny shrubs. The passage demonstrates that beauty is an illusion, a trick of the sea and sunlight on the dull terrain, or man-made: a white chapel and planted garden that punctuate the leaden landscape. In The Lady of Sorrows the isolation and insulation of islands is similarly emphasized through two arrivals by sea: the shipwreck in sight of Kalkos in the historical prologue, and the arrival of Hermes's oceangoing cruiser, Aphrodite, in the opening pages of the contemporary story. Together, the literary (graphic) and narrative (descriptive) maps, to use Sally Bushell's terms, clearly delineate a bounded environment which allows "for a limited number of possible intersections of person, event, and location" (Bushell, 2012, p. 154) in each of Zouroudi's island mysteries. The purpose of the literary map in The Messenger of Athens is not to provide the reader with a clue to the mystery or to aid the investigator-as, for example, the floor plan in Agatha Christie's The Mysterious Affair at Styles (1920) and the map in Evil Under the Sun (1941) dobut to signal the strong sense of place in the text that follows. Moreover, the boundedness of the island is emphasized by the fact that the full circumference of Thiminos is visible on the map, whereas the bleeding edges of the maps of the island of Kalkos in The Lady of Sorrows and the island of Mithros in The Bull of Mithros (that is, where cartographic detail extends beyond the edges of the map) signal a larger island or landmass.

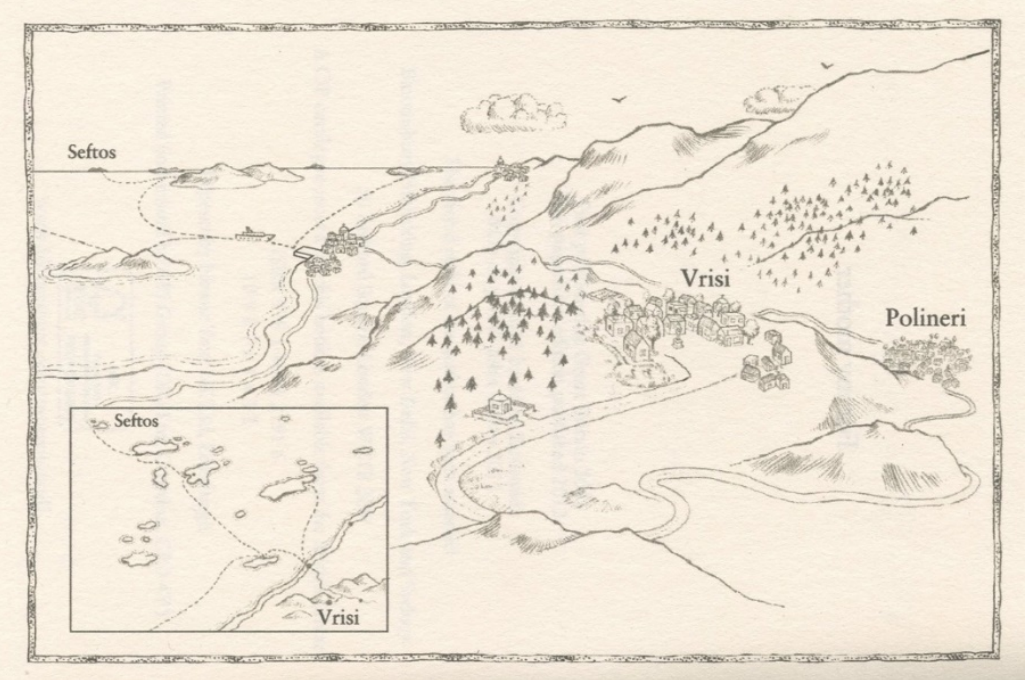

Figure 4: Map by John Gilkes. Anne Zouroudi, The Whispers of Nemesis, Bloomsbury, 2012.

Maps are more than decorative and should never be read "merely as an illustration" (Bushell, 2012, p. 153) (and, I would add, nor should illustrations ever be read merely as illustrations). The literary map in The Whispers of Nemesis (Figure 4) serves a different function to that of the map in A Messenger of Athens. In The Whispers of Nemesis the purpose of the map is not to emphasize a sense of place per se, but to emphasize a sense of mobility and the archipelagic setting of the novel: thus both the boundedness of islands and their peripheral relationships to each other are accentuated. Neither the main map nor the inset provide the reader with any sense of the topography of the "Long, flat and featureless" island of Seftos (Zouroudi, 2012, p. 47), but rather highlight the isolation of Seftos, which is further signalled by its position on the horizon of the main map. Somewhat paradoxically, perhaps, the dotted 
lines that chart the inter-island ferry routes (as well as the small ferry depicted on the main map) simultaneously emphasize both this sense of insulation and isolation and the ferry routes that connect them. In his study of ferry mobilities in British Columbia, Philip Vannini (2011, p. 250) suggests that "islanders opt for lifestyles which 'protect' them from the ills of less desirable places." In Zouroudi's The Whispers of Nemesis, by choosing to make his home on "the little island," the "man they call the hermit" opts for a lifestyle which "protects" him from the consequences of the crime he has committed. However, by highlighting the ferry routes that connect the islands, the literary map that precedes the text of this novel signals the porous nature of island boundaries, while also anticipating the means Zouroudi's enigmatic detective will use to solve the crime. As travel between the islands is only possible by sea, Hermes Diaktoros is able to beard the murderer in his island den by following in the wake of the ferries taken by his daughter. The mobility of the hero, the ability of Hermes to move between islands - be it aboard a ferry or the "broad and well-balanced" boat of the friendly shopkeeper on Seftos (Zouroudi, 2012, p. 253)—reassures the reader that the detective's control is not circumscribed by the boundaries of a single island, but has archipelagic reach, and that no island, however small, is beyond his ken. As the reader discovers in the first chapter of The Bull of Mithros, "In Mithros's harbour, no boat ever came or went unnoticed. [...] all were watched by somebody, somewhere" (Zouroudi, 2013, p. 11).

The editions of Jeffrey Siger's four island-set Andreas Kaldis mysteries published by Poison Pen Press all include maps, which, like all elements of paratext, as Gérard Genette (1997) has explained (see Paratexts: Thresholds of Interpretation), both accompany and extend a text. Murder in Mykonos includes a map of the Island of Mykonos; Target Tinos, Mykonos After Midnight, and Santorini Caesars each contain an outline map of the Cyclades Islands and a larger-scale outline map of the island which provides the principal setting for that novel, both on the same page, as well as an image of the Church of Panagia Evangelistria (Target Tinos), a map of Mykonos Town (Mykonos After Midnight), and (perhaps somewhat incongruously) a map of the Athens Metro (Santorini Caesars). Whereas the style of John Gilkes's maps in Zouroudi's novels may remind the reader of those commonly found in (island-set) fantasy fiction, and, like the illustrations in $19^{\text {th }}$-century adventure fiction, are created from the text, the maps included in Target Tinos (Figure 5) precede the creation of the text. In other words, in Zouroudi's novels the literary maps draw on the narrative maps, whereas in Siger's novels the narrative maps draw on the literary maps, on the actual geography of, in this novel, the Cyclades Islands and Tinos. By including two maps, Siger emphasizes both the bounded nature of Tinos, and invites readers to "think with the archipelago" (Pugh, 2013, p. 9) by considering the pattern of islands and the geographical position of Tinos in relation to the geography of the Cyclades.

Indeed, while fantasy fiction may be the most logical starting place, it is useful, too, to look to crime fiction to explore the archipelagic turn in island studies. As Fletcher and I argue in Island Genres, Genre Islands, fantasy writers have been thinking with the archipelago for decades. Now crime writers, too, are embracing what Elizabeth DeLoughrey (2001, p. 23) terms "a system of archipelagraphy — that is, a historiography that considers chains of islands in fluctuating relationship to their surrounding seas, islands and continents." This is particularly evident in crime fiction set in and around islands: Greek islands, Scottish islands (Peter May, Anne Cleeves), Swedish islands (Mari Jungstedt, Viveca Sten), and Pacific islands (G.W. Kent, John Enright). 


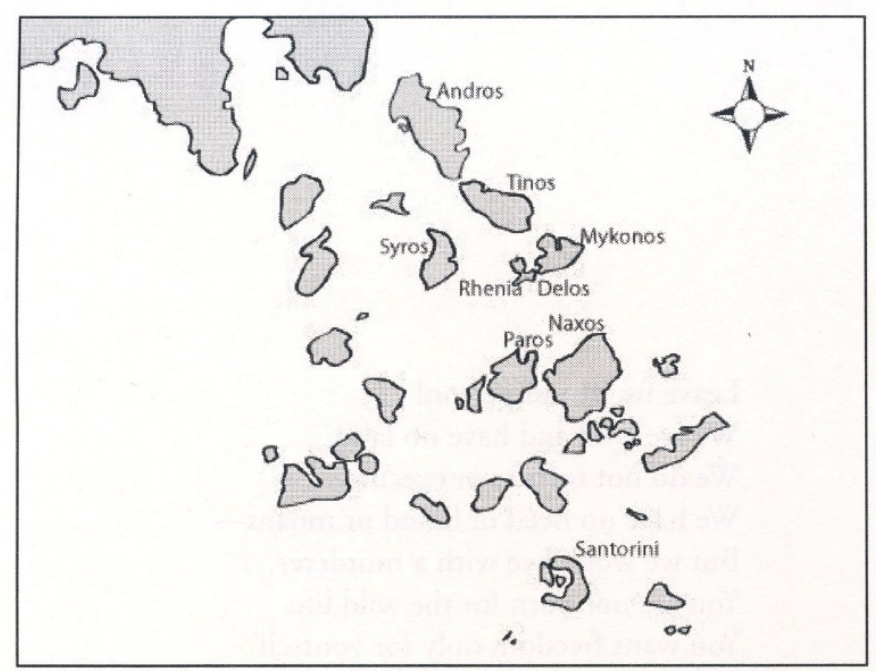

The Cyclades Islands

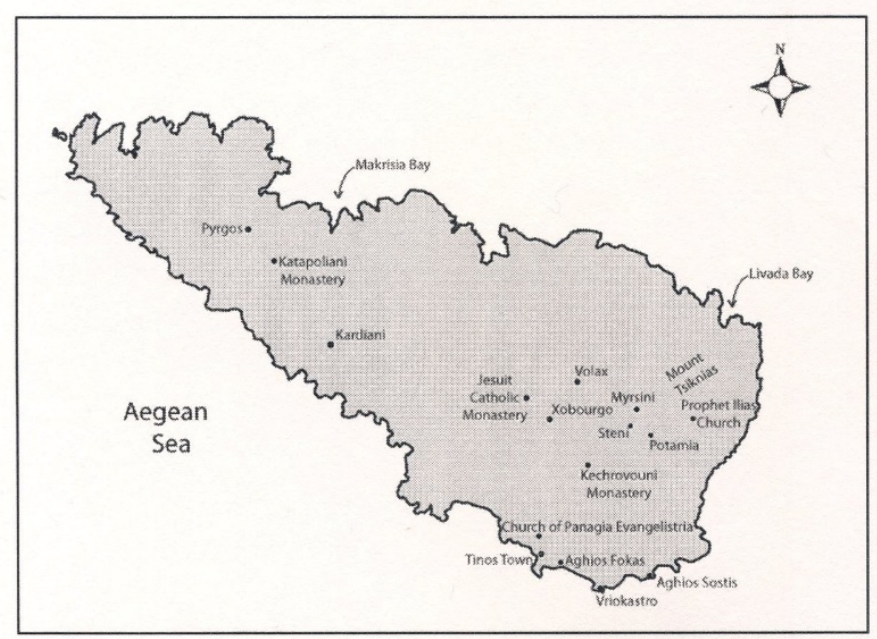

The Island of Tinos

Figure 5: Jeffrey Siger, Target Tinos, 2014, Poisoned Pen Press.

Regardless of these differences, however, in diverse ways the paratextual mapswhether fictional, as in Zouroudi's novels, or real-place maps, as in Siger's-assist the reader in interpreting the geography of the novel and support the narrative maps, or descriptions of place, present in the text. In this the maps operate in ways similar to the map in Robert Louis Stevenson's Treasure Island (1883), to cite perhaps the most famous map in island-set fiction, or, more generally, in the way illustrations are intended to interpret particular scenes in $19^{\text {th }}$ century adventure novels. Further, the presence of the maps in these books highlights the connections between islands and crime fiction. Specifically, they signal the importance of spatiality in island-set crime fiction: the influence of island geography on the structure of the crime plot, and, conversely, the way the spatial restrictions of clue-puzzle mysteries (lockedroom mysteries, country-house mysteries, and so on) can inflect our reading of islands. 


\section{Island genre sites, island tourist sites}

The visual dimensions of these novels, the covers and maps of Zouroudi's novels in particular, draw attention to the correlation between islands as tourist sites and islands as genre sites. Tourism and reading genre fiction are both leisure activities which involve a literal or metaphorical journey (or a literal and metaphorical one when a crime novel is read in situ), and which are, as John Urry $(2002$, p. 3) observes in relation to tourism, embraced by "[a] substantial proportion of the population of modern societies." Urry (2002, p. 3) argues that "Places are chosen to be gazed upon because there is an anticipation [...] of intense pleasures, either on a different scale or involving different senses from those customarily encountered." That anticipation of pleasure can also be "constructed and sustained" through reading genre fiction which (like tourist guidebooks) frequently provides detailed descriptions of the local landscape, the local culture, and the local food and drink. Alex Mavros is a connoisseur of galaktoboureko, while Hermes Diaktoros's many meals taken in traditional kafenions are described in glorious detail:

The waiter brought out the first small plates: tiny whole shrimps pan-fried with ouzo, aubergine dolmades filled with spiced pork and rice, vivid beetroot hummus with home-baked pitta bread. [...]

The waiter cleared away the first plates and brought three more: crispy courgette fritters made with mint and sheep's cheese, slices of wild boar salami, haricot beans cooked with rabbit and mountain herbs. [...] the waiter reappeared.

"Octopus baked with orzo pasta," he said, laying the dish on the table. "Tart of Swiss chard and feta. Duck braised with Metaxa, milk-fed goat with lemon and juniper and a warm salad of green beans and toasted almonds." (Zouroudi, 2016, pp. 155-158)

Such culinary descriptions remind the tourist reader of his or her holiday and help him or her to identify with the island, with the island detective, who, like the reader, is often a visitor to the location, there to solve a crime before, like the tourist, returning home. Similarly, in Siger's Mykonos After Midnight, there are detailed descriptions of the island's geography and history, frequent references to the island's tourism, and to movement between the islands. Indeed, the reader is constantly reminded of the archipelagic setting of the series as a whole, as, for example, when Andreas and his detective, Kouros, gaze at the "span of islands spread out across a rose-blue sea running off to the horizon" (Siger, 2013, p. 151), or when Kouros lists the islands he can see from Mykonos: Naxos, Paros, Ikaria, Stapodia, Donousa, Amorgos (Siger, 2013, p. 151). Again the reader is invited to share Kouros's tourist view of the islands, or even to identify with the author who was once a tourist, but stayed on to write fiction.

These and other numerous references to Greek island culture and tourism which pervade the works of all three authors beg the question: do islands advertise books or do books advertise islands?

\section{Conclusion}

As Katrin Dautel and Kathrin Schödel (2017, p. 229) note, "Scholarship of insular spaces both as geographical as well as metaphorical places situates island studies within the so-called spatial 
turn in literary and cultural studies over the past decades with its focus on the analysis of fictional spaces at the interface of cultural and social sciences." Such studies have, largely, concentrated on literary representations of islands (real and metaphorical) in texts (see Crane \& Fletcher, 2017). This paper moves outside the text per se to argue the case for paying closer attention to the paratextual life of islands found on the covers and maps that accompany and extend island crime fiction and the ways those elements both respond to and inform the tourist reader's experiences and expectations of islands. It provides a geographically focused analysis of island crime paratext in order to show that reading beyond the text of popular genres can offer new ways to re-think islands. As Lisa Fletcher, Beth Driscoll, and Kim Wilkins have argued in relation to $21^{\text {st }}$-century Australian romance, the study of popular fiction can only benefit from critics straddling literary and cultural studies, publishing studies, and book history (Fletcher et al., 2018). Similarly, the study of island-set crime fiction can only benefit from critics straddling literary studies and island studies to produce alternative approaches to the reading of both popular crime fiction (or, indeed, other popular fiction genres) and islands.

\section{References}

Amis, K. [Markham, R.] (2015). Colonel Sun. London: Vintage. (Original published 1968.) Baldacchino, G. (2012). The lure of the island: a spatial analysis of power relations. Journal of Marine and Island Cultures, 1(2), 55-62. https://doi.org/10.1016/j.imic.2012.11.003

Bushell, S. (2012). The slipperiness of literary maps: Critical geography and literary cartography. Cartographica, 47(3), 149-160. https://doi.org/10.3138/carto.47.3.1202

Christie, A. (2006). Triangle at Rhodes. In Murder in the Mews (pp. 247-80). London: HarperCollins. (Original published 1937.)

Crane, R., \& Fletcher, L. (2017). Island genres, genre islands: conceptualisation and representation in popular fiction. London: Rowman \& Littlefield.

Crouch, J. (2014). The long fall. London: Headline.

Cussler, C. (2008). The Mediterranean caper. New York: Berkley. (Original published 1973.)

Dautel, K., \& Schödel, K. (2017). Island fictions and metaphors in contemporary literature. Island Studies Journal 12(2), 229-238. https://doi.org/10.24043/isj.40

DeLoughrey, E. (2001). "“The litany of islands, the rosary of archipelagoes: Caribbean and Pacific archipelagraphy." Ariel: A Review of International English Literature, 32(1), 21-52.

Filippou, F. (2015). Crime fiction during the crisis. In N. Lemos \& E. Yannakakis (Eds.) Critical times, critical thoughts: contemporary Greek writers discuss facts and fiction (pp. 144159). Newcastle upon Tyne: Cambridge Scholars.

Fletcher, L., Driscoll, B., \& Wilkins, K. (2018). Genre worlds and popular fiction: the case of twenty-first-century Australian romance. Journal of Popular Culture, 51(4), 997-1015. https://doi.org/10.1111/jpcu.12706

Genette, G. (1997). Paratexts: thresholds of interpretation. Trans. by Jane E. Lewin. Cambridge: Cambridge University Press. https://doi.org/10.1017/cbo9780511549373

Gillis, J.R. (2003). Taking history offshore: Atlantic islands in European minds. In R. Edmond \& V. Smith (Eds.) Islands in history and representation (pp. 19-31). London: Routledge.

Goddard, R. (1990). Into the blue. London: Bantam.

Higgins, J. (1970). Night judgement at Sinos London: Hodder \& Stoughton.

Higgins, J. [Patterson, H.] (1963). The dark side of the island. London: John Long. 
Johnston, P. (2014). The white sea. Sutton, UK: Crème de la Crime.

Johnston, P. (2012). The silver stain. Sutton, UK: Crème de la Crime.

Johnston, P. (2002/2009). Crying blue murder [A Deeper Shade of Blue]. Richmond, UK: Mira.

Kaisidou, V. (2018). Behind crime and depravity: moral ambiguity and social constructions of evil in contemporary Greek detective fiction. http://anthropino.gr/ $\alpha \rho \theta \rho \alpha / 58 /$

Leane, E. (2016). Unstable places and generic places: thrillers set in Antarctica. In L. Fletcher (Ed.) Popular fiction and spatiality: Reading genre settings (pp. 25-43). London: Palgrave Macmillan. https://doi.org/10.1057/978-1-137-56902-8 3

Luria, S. (2011). Spatial literacies: geotexts. In M. Dear, J. Ketchum, S. Luria, \& D. Richardson (Ed.) Geohumanities: art, history, text at the edge of place (pp. 67-70). London: Routledge. https://doi.org/10.1111/j.1467-9787.2012.00780 3.x

MacLean, A. (1986). Santorini. London: Collins.

Maris, Y. (2016). Murder in Mykonos. Trans. by James Johnstone. Athens: ETP Books. (Original published 1958.)

Matthews, N. (2007). Introduction. In N. Matthews \& N. Moody (Ed.) Judging a book by its cover: fans, publishers, designers, and the marketing of fiction (pp. xi-xxi). Aldershot: Ashgate. https://doi.org/10.1108/00242530910969866

Pezzotti, B. (2014). The importance of place in contemporary Italian crime fiction: a bloody journey. Madison, NJ: Fairleigh Dickinson University Press. (Original published 2012.)

Phillips, A. (2007). How books are positioned in the market: reading the cover. In N. Matthews \& N. Moody (Eds.) Judging a book by its cover: Fans, publishers, designers, and the marketing of fiction (pp. 19-30). Farnham: Ashgate. https://doi.org/10.4324/9781315251318

Priestman, M. (2003). Introduction. In M. Priestman (Ed.) The Cambridge companion to crime fiction (pp. 1-6). Cambridge: Cambridge University Press. https://doi.org/10.1017/ccol0521803993.001

Pugh, J. (2013). Island movements: thinking with the archipelago. Island Studies Journal, 8(1), 9-24.

Siger, J. (2016). Santorini Caesars. Scottsdale: Poisoned Pen.

Siger, J. (2014). Target Tinos. Scottsdale: Poisoned Pen. (Original published 2012.)

Siger, J. (2013). Mykonos after midnight. Scottsdale: Poisoned Pen.

Siger, J. (2010). Murder in Mykonos. Scottsdale: Poisoned Pen. (Original published 2009.)

Stevenson, R.L. (2011). Treasure Island. Oxford: Oxford University Press. (Original published 1883.)

Taglioni, F. (2011). Insularity, political status and small insular spaces. Shima, 5(2), 45-67.

Urry, J. (2002). The tourist gaze: leisure and travel in contemporary societies. $2 \mathrm{nd}$ ed. London: Sage. Vannini, P. (2011). Constellations of ferry (im)mobility: islandness as the performance and politics of insulation and isolation. Cultural Geographies, 18(2), 249-271. https://doi.org/10.1177/1474474010397597

Zouroudi, A. (2016). The gifts of Poseidon. London: unknown publisher.

Zouroudi, A. (2013). The bull of Mithros. London: Bloomsbury. (Original published 2012.)

Zouroudi, A. (2012). The whispers of Nemesis. London: Bloomsbury. (Original published 2011.)

Zouroudi, A. (2011a). The messenger of Athens. London: Bloomsbury. (Original published 2007.)

Zouroudi, A. (2011b). The lady of sorrows. London: Bloomsbury. (Original published 2010.) 